Amien, S. • M. F. Wiguna

\title{
Pupuk anorganik sebagai alternatif media untuk pertumbuhan eksplan nilam (Pogostemon cablin Benth) kultivar Sidikalang dan Tapaktuan secara in-vitro
}

\section{An inorganic fertilizers as alternative for growing explant of pogostemon (Pogostemon cablin Benth.) Sidikalang and Tapaktuan cultivars in-vitro}

\author{
Diterima : 15 Juli 2016/Disetujui : 10 Agustus 2016 / Dipublikasikan : 30 Agustus 2016 \\ CDepartment of Crop Science, Padjadjaran University
}

\begin{abstract}
Tissue culture technology is known as an expensive technology, especially for providing media. Previous experiments showed that inorganic fertilizer can be used as a medium in vitro. But the result has to be investigated in more detail. This research was conducted to obtain the appropriate inorganic fertilizer media for growing of Pogostemon cultivars (Pogos-temon cablin Benth) cv. Sidikalang and Tapak Tuan. This research was held at tissue culture technology laboratory of plant breeding, Faculty of Agriculture, Padjadjaran University from May to August 2010. Each replication consisted of two bottles of culture. The first factor was Pogostemon Cultivars (n) namely Sidikalang $\left(\mathrm{n}_{1}\right)$ and Tapaktuan $\left(\mathrm{n}_{2}\right)$. The second factor was several inorganic fertilizer media, namely MS $\left(\mathrm{m}_{1}\right)$, Gandasil $\left(\mathrm{m}_{2}\right)$, Growmore $\left(\mathrm{m}_{3}\right)$, Hyponex $\left(\mathrm{m}_{4}\right)$ and Vitabloom $\left(\mathrm{m}_{5}\right)$. A Completely Randomized Block design with factorial pattern was used with two treatments and replicated three times. The result showed that was no interaction between cultivars and media for the character time of initial shoot formation, high shoots, number of leaves, number of roots, length of roots, and wet weight of plantlets. MS media compared to four inorganic fertilizer media showed the best media for the character number of leaves with an average of 28, high shoots with an average of $2,25 \mathrm{~cm}$ and wet weight of plantlet with an average of $0,69 \mathrm{~g}$. Hyponex media showed the best response for the character number of roots with an average of 56 and root length with an average of $1,85 \mathrm{~cm}$.
\end{abstract}

Keywords : Patchouli · Tissue culture · Inorganic fertilizers $\cdot$ Planlet

\footnotetext{
Dikomunikasikan oleh Yudithia Maxiselly

Amien, S. ${ }^{1}$ M. F. Wiguna ${ }^{2}$

${ }^{1}$ Staff Pengajar Departemen Budidaya Pertanian, Fakultas

Pertanian, Universitas Padadjaran

${ }^{2}$ Alumni Dept. Budidaya Pertanian, Faperta Unpad

Jl. Raya Bandung-Sumedang Km 21, Jatinangor Sumedang

Korespondensi: e-mail:suseno@unpad.ac.id
}

Sari. Kultur jaringan selama ini dipahami oleh sebagian masyarakat merupakan suatu teknologi yang mahal, terutama dalam menyediakan bahan kimia untuk media. Hasil percobaan sebelumnya menunjukkan bahwa percobaan dengan media pupuk anorganik dapat digunakan sebagi media tanam in-vitro. Namun media tersebut belum diteliti secara rinci manfaatnya untuk tanaman nilam. Penelitian ini dilakukan untuk memperoleh media pupuk anorganik yang sesuai untuk pertumbuhan kultivar nilam (Pogostemon cablin Benth) Sidikalang dan Tapak Tuan. Penelitian dilakukan di laboratorium teknologi kultur jaringan Pemuliaan Tanaman Fakultas Pertanian Universitas Padjadjaran dari bulan Mei sampai Agustus 2010. Rancangan yang digunakan adalah rancangan acak lengkap pola faktorial dengan dua faktor perlakuan dan diulang sebanyak tiga kali. Faktor pertama adalah kultivar nilam (n) yang terdiri dari dua taraf yaitu kultivar Sidikalang $\left(\mathrm{n}_{1}\right)$ dan Tapak-tuan $\left(\mathrm{n}_{2}\right)$. Faktor kedua adalah media yang digunakan $(\mathrm{m})$, terdiri dari lima taraf yaitu media MS $\left(\mathrm{m}_{1}\right)$, Gandasil $\left(\mathrm{m}_{2}\right)$, Growmore $\left(\mathrm{m}_{3}\right)$, Hyponex $\left(\mathrm{m}_{4}\right)$ dan Vitabloom $\left(\mathrm{m}_{5}\right)$. Hasil penelitian menunjukkan tidak terdapat interaksi antara kultivar dan media untuk karakter waktu pembentukan tunas, tinggi tunas, jumlah daun, jumlah akar, panjang akar, dan bobot basah plantlet. Media MS dibandingkan dengan empat media pupuk anorganik yang diuji merupakan media terbaik untuk karakter jumlah daun dengan ratarata 28 buah, tinggi tunas dengan rata-rata $2,25 \mathrm{~cm}$ dan bobot basah plantlet dengan rata-rata 0,69 $\mathrm{g}$. Media hyponex menunjukkan pengaruh terbaik untuk karakter jumlah akar dengan rata-rata $56 \mathrm{~cm}$ dan panjang akar dengan rata-rata $1,85 \mathrm{~cm}$.

Kata kunci : Nilam · Kultur jaringan · Media pupuk anorganik · Planlet 


\section{Pendahuluan}

Tanaman nilam (Pogostemon cablin Benth) merupakan tanaman penghasil minyak atsiri nilam (patchouli oil), Kontribusi minyak nilam sebagai sumber devisa negara dari minyak atsiri sebesar $60 \%$ (Krismawati, 2005). Peluang untuk meningkatkan nilai ekspor minyak nilam masih cukup besar seiring dengan semakin meningkatnya permintaan terhadap bahan baku industri kosmetik, makanan dan farmasi. Minyak nilam memiliki banyak keunggulan jika dibandingkan dengan minyak atsiri lainnya karena minyak nilam bersifat (fiksatif) atau mengikat bahan yang lain sehingga belum ditemukan bahan subsitusi untuk industri kosmetik (Nuryani, 2006).

Sentra produksi tanaman nilam di Indonesia terdapat di daerah Aceh, Sumatera, Bengkulu Lampung, Sumatera Barat, Jawa barat, Jawa Tengah dan Jawa Timur. Tahun 2002 luas areal pertanaman nilam sekitar 21.602 ha, namun produktivitas minyak nilam masih rendah rata-rata $97,53 \mathrm{~kg} / \mathrm{ha}$ (Mangun, 2008).

Terdapat beberapa jenis tanaman nilam yang telah tumbuh dan berkembang di Indonesia, seperti nilam jawa (Pogostemon heyneanus), nilam sabun (Pogostemon hortensis), dan nilam aceh (Pogostemon cablin). Nilam aceh lebih dikenal dan telah ditanam secara luas oleh petani hal ini dikarenakan kadar kualitas minyak nilam aceh lebih tinggi dari nilam jawa dan nilam sabun. Hasil pemuliaan yang dilakukan oleh Balitro diperoleh kultivar nilam yang berkadar minyak relatif tinggi $(>2,5 \%)$, yaitu Kultivar Lhoksemauwe, Sidikalang dan Tapaktuan (Balitro, 2006).

Perbanyakan tanaman nilam secara konvensional biasanya melalui organ vegetatif. Perbanyakan vegetatif yang sering dilakukan biasanya melalui stek batang dan panen saat tanaman berumur sekitar 6-7 bulan (Mangun, 2008). Perbanyakan tanaman nilam melalui kultur jaringan merupakan salah satu teknologi alternatif yang dapat digunakan untuk memproduksi bibit nilam. Perkembangan penerapan teknologi kultur jaringan di Indonesia sangat lambat jika dibandingkan dengan negara lain hal ini karena dibutuhkan biaya yang relatif tinggi untuk pengadaan alat dan bahan laboratorium serta diperlukan keahlian khusus pelaksana. Laboratorium kultur jaringan dapat disederhanakan dengan melakukan modifikasi peralatan dan bahan yang digunakan, seperti modifikasi media tanam dengan menggunakan media pupuk anorganik yang murah dan praktis digunakan, sehingga bisa diterapkan secara sederhana dalam skala rumah tangga (Hadi, 2006).

Keberhasilan kultur jaringan sangat ditentukan oleh media yang digunakan. Media Murashige and Skoog (MS) merupakan media dasar yang paling sering digunakan dalam kultur jaringan karena memiliki kelengkapan unsur hara makro dan mikro yang dibutuhkan oleh tanaman (Gunawan, 1992). Media kultur jaringan dapat dimodifikasi dengan menggunakan media berbahan dasar pupuk. Media kultur dengan bahan dasar pupuk anorganik telah menghasilkan pertumbuhan pada tanaman anggrek, sehingga media pupuk anorganik dapat menjadi alternatif pengganti media dasar kultur jaringan (Soedjono dan Kamidjono, 1992). Pupuk anorganik yang biasa digunakan dalam kultur jaringan adalah growmore, vitabloom, hyponex dan gandasil. Pupuk tersebut berbentuk butiran dan memiliki keunggulan yaitu, baik untuk pertumbuhan vegetatif, komposisi lengkap terdiri dari unsur hara makro dan mikro.

Selain media, faktor lain yang menentukan keberhasilan kultur jaringan adalah eksplan. Pengaruh eksplan sebagai faktor genotip untuk pertumbuhan dan perkembangan tanaman bergantung pada media sebagai lingkungan. Keadaan lingkungan dapat mempengaruhi penampakan gen karena penampakan fenotipe adalah akibat dari interaksi antara genotipe dengan lingkungan. Penampilan fenotipik dari genotip yang sama, akan memberikan respon yang berbeda apabila ditanam pada lingkungan yang berbeda, demikian juga penampilan fenotipik genotip berbeda, tidak akan sama walaupun ditanam pada lingkungan yang sama (Crowder, 1993).

Penelitian ini bertujuan untuk memperoleh media pupuk anorganik yang sesuai untuk pertumbuhan Kultivar Sidikalang dan Tapaktuan.

\section{Bahan dan Metode}

Percobaan dilakukan di laboratorium kultur jaringan Pemuliaan Tanaman Fakultas Pertanian Universitas Padjadjaran. Bahan-bahan yang digunakan dalam percobaan ini meliputi tunas in-vitro kultivar Sidikalang dan Tapak Tuan sebagai sumber eksplan. Media yang digunakan adalah MS, pupuk anorganik Gandasil, Growmore, Hyponex dan Vitabloom. Selain itu diperlukan gula pasir sebagai sumber karbohidrat, agar "swallow" sebagai bahan pemadat, 
$\mathrm{HCl}, \mathrm{NaOH}$, spiritus, alkohol 95\% dan 70\%, aquades, bayclin dengan bahan aktif Natrium hipoklorit ( $\mathrm{NaClO}$ ) 5,25\%, dan detergen.

Pada tahap persiapan alat yang digunakan adalah timbangan elektrik, gelas ukur, gelas piala, pipet, PH meter, labu erlenmeyer, pengaduk magnetik, batang pengaduk, kompor listrik, botol kultur, alumunium foil, karet gelang, lemari es, dan autoclave. Tahap induksi alat yang digunakan yaitu laminer air flow, petridish, kertas saring, pinset, skalpel, bunsen, dan handsprayer. Pada tahap inkubasi alat yang digunakan adalah rak kultur, air conditioner (AC), lampu TL, termohigrometer.

Metode penelitian yang digunakan adalah metode eksperimen Rancangan Acak Lengkap (RAL) pola faktorial dengan tiga ulangan dan terdiri dari dua faktor. Sebagai faktor pertama adalah tanaman nilam dari kultivar Sidikalang dan Tapak Tuan. Faktor kedua terdiri dari lima taraf media yaitu media dasar MS sebagai kontrol, media pupuk anorganik Gandasil-D, Growmore, Hyponex, Vitabloom $1 \mathrm{~g} / 1$ ditambah vitamin MS dengan konsentrasi $10 \mathrm{ml} / 1$ pada masing-masing media. Setiap unit percobaan terdiri dari dua botol kultur sehingga jumlah seluruh botol kultur terdapat 60 botol kultur. Tata letak botol kultur dapat dilihat pada lampiran 6. Faktor pertama terdiri dari dua taraf (n) yaitu dua kultivar nilam.

$\mathrm{n} 1=$ Nilam kultivar Sidikalang.

n2 = Nilam kultivar Tapaktuan .

Faktor kedua adalah media MS dan pupuk anorganik, terdiri dari lima taraf $(\mathrm{m})$ yaitu

$\mathrm{m} 1=$ Media MS.

$\mathrm{m} 2=$ Media Gandasil $1 \mathrm{~g} / 1+$ Vitamin MS 10ml/1 $\mathrm{m} 3=$ Media Growmore $1 \mathrm{~g} / 1+$ Vitamin MS 10ml/1 $\mathrm{m} 4=$ Media Hyponex $1 \mathrm{~g} / 1+$ Vitamin MS 10ml/1 m5 = Media Vitabloom $1 \mathrm{~g} / 1+$ Vitamin MS10ml/1

\section{Hasil dan Pembahasan}

Berdasarkan hasil uji $\mathrm{F}$ menunjukkan tidak terjadi interaksi antara genotip dengan media. Hasil uji $\mathrm{F}$ untuk perlakuan kultivar secara mandiri menunjukkan nilai yang tidak berbeda nyata pada semua karakter. Berdasarkan hasil uji $\mathrm{F}$ menunjukkan bahwa perlakuan media secara mandiri menunjukkan nilai yang signifikan pada karakter tinggi tunas, jumlah daun, jumlah akar, panjang akar dan bobot basah planlet (Tabel 1).

Hasil uji $\mathrm{F}$ tersebut kemudian dilanjutkan dengan uji lanjut pada masing-masing faktor yang berbeda nyata dengan menggunakan uji Duncan taraf 5\%. Data yang diperoleh pada pengamatan utama untuk karakter bobot basah, tinggi tunas, jumlah tunas dan panjang akar ditransformasi dengan menggunakan transformasi $\sqrt{(X)+0,5}$ (Gasperz, 1995), karena data yang diperoleh memiliki sebaran yang tidak normal, terdapat data yang nol dan kurang dari sepuluh $(<10)$.

\section{Tabel 2. Pengaruh Media terhadap Karakter} Tinggi Tunas.

\begin{tabular}{lcc}
\hline \hline \multicolumn{1}{c}{ Perlakuan } & \multicolumn{2}{c}{ Nilai Rata-rata Tinggi Tunas $(\mathrm{cm})$} \\
\hline $\mathrm{m} 1=$ MS & 2.25 & $\mathrm{E}$ \\
$\mathrm{m} 2=$ Gandasil & 1.53 & $\mathrm{~B}$ \\
$\mathrm{~m} 3=$ Growmore & 1.20 & $\mathrm{~A}$ \\
$\mathrm{~m} 4=$ Hyponex & 1.74 & $\mathrm{C}$ \\
$\mathrm{m} 5=$ Vitabloom & 2.03 & $\mathrm{D}$ \\
\hline \hline
\end{tabular}

Keterangan: Nilai rata-rata yang ditandai dengan huruf kecil yang sama pada kolom yang sama, dinyatakan tidak berbeda nyata menurut uji jarak berganda Duncan taraf 5\%.

Tabel 3. Pengaruh Media terhadap Karakter Jumlah Daun.

\begin{tabular}{|c|c|c|}
\hline Perlakuan & \multicolumn{2}{|c|}{$\begin{array}{c}\text { Nilai Rata-rata } \\
\text { Jumlah Daun (Buah) }\end{array}$} \\
\hline $\mathrm{m} 1=\mathrm{MS}$ & 28 & $\mathrm{D}$ \\
\hline $\mathrm{m} 2=$ Gandasil & 15 & A \\
\hline $\mathrm{m} 3=$ Growmore & 15 & $\mathrm{~A}$ \\
\hline m4 = Hyponex & 24 & $\mathrm{C}$ \\
\hline m5 = Vitabloom & 17 & B \\
\hline
\end{tabular}

Keterangan: Nilai rata-rata yang ditandai dengan huruf kecil yang sama pada kolom yang sama, dinyatakan tidak berbeda nyata menurut uji jarak berganda Duncan taraf $5 \%$.

Tabel 1. Nilai uji-F pada Karakter-karakter Pengamatan Utama.

\begin{tabular}{cccccccc}
\hline \hline & Waktu Pembentukan & Tinggi & Jumlah & Jumlah & Panjang & Jumlah & Bobot Basah \\
Karakter & Tunas Baru & Tunas & Daun & Akar & Akar & Planlet & Planlet \\
\hline $\mathrm{N}$ & $0,64^{\mathrm{ns}}$ & $2,68^{\mathrm{ns}}$ & $0,34^{\mathrm{ns}}$ & $3,76^{\mathrm{ns}}$ & $1,05^{\mathrm{ns}}$ & $0,20^{\mathrm{ns}}$ & $1,49^{\mathrm{ns}}$ \\
$\mathrm{M}$ & $0,48^{\mathrm{ns}}$ & $8,66^{*}$ & $11,35^{*}$ & $4,85^{*}$ & $6,71^{*}$ & $2,57^{\mathrm{ns}}$ & $14,80^{*}$ \\
$\mathrm{Nm}$ & $0,68^{\mathrm{ns}}$ & $0,42^{\mathrm{ns}}$ & $0,80^{\mathrm{ns}}$ & $0,02^{\mathrm{ns}}$ & $2,04^{\mathrm{ns}}$ & $0,10^{\mathrm{ns}}$ & $2,19^{\mathrm{ns}}$ \\
\hline \hline
\end{tabular}

$\overline{\text { Keterangan }: \mathrm{ns}=\text { tidak berbeda nyata; }{ }^{*}=\text { Berbeda nyata pada taraf } 5 \% ; \mathrm{N}=\text { Kultivar; } \mathrm{Nm}=\text { Interaksi Kultivar }}$ dengan Media; $\mathrm{M}=$ Media. 
Tabel 4. Pengaruh Media terhadap Karakter Jumlah Akar.

\begin{tabular}{lrl}
\hline \hline \multicolumn{1}{c}{ Perlakuan } & \multicolumn{2}{c}{ Nilai Rata-rata } \\
& Jumlah Akar (Buah) \\
\hline $\mathrm{m} 1$ = MS & 31 & $\mathrm{D}$ \\
$\mathrm{m} 2$ = Gandasil & 9 & $\mathrm{~A}$ \\
$\mathrm{~m} 3$ = Growmore & 12 & $\mathrm{~B}$ \\
$\mathrm{~m} 4$ = Hyponex & 56 & $\mathrm{E}$ \\
$\mathrm{m} 5$ = Vitabloom & 27 & $\mathrm{C}$ \\
\hline \hline
\end{tabular}

Keterangan: Nilai rata-rata yang ditandai dengan huruf kecil yang sama pada kolom yang sama, dinyatakan tidak berbeda nyata menurut uji jarak berganda Duncan taraf 5\%.

Tabel 5. Pengaruh Media terhadap Karakter Panjang Akar.

\begin{tabular}{|c|c|}
\hline Perlakuan & $\begin{array}{c}\text { Nilai Rata-rata } \\
\text { Panjang Akar (cm) }\end{array}$ \\
\hline $\mathrm{m} 1=\mathrm{MS}$ & 0.91 \\
\hline $\mathrm{m} 2$ = Gandasil & 0.90 \\
\hline $\mathrm{m} 3=$ Growmore & 0.43 \\
\hline m4 = Hyponex & 1.85 \\
\hline m5 = Vitabloom & 1.11 \\
\hline
\end{tabular}

Keterangan: Nilai rata-rata yang ditandai dengan huruf kecil yang sama pada kolom yang sama, dinyatakan tidak berbeda nyata menurut uji jarak berganda Duncan taraf 5\%.

Tabel 6. Pengaruh Media terhadap Karakter Bobot Basah Planlet.

\begin{tabular}{|c|c|}
\hline Perlakuan & $\begin{array}{c}\text { Nilai Rata-rata } \\
\text { Bobot Massa Planlet }(\mathrm{g})\end{array}$ \\
\hline $\mathrm{m} 1=\mathrm{MS}$ & $0.69 \quad \mathrm{C}$ \\
\hline $\mathrm{m} 2=$ Gandasil & 0.08 \\
\hline $\mathrm{m} 3=$ Growmore & $0.12 \quad \mathrm{~A}$ \\
\hline m4 = Hyponex & 0.33 \\
\hline m5 = Vitabloom & 0.39 \\
\hline
\end{tabular}

Keterangan: Nilai rata-rata yang ditandai dengan huruf kecil yang sama pada kolom yang sama, dinyatakan tidak berbeda nyata menurut uji jarak berganda Duncan taraf 5\%.

Hasil analisis statistik pada semua karakter utama yang diamati menunjukkan tidak terjadi interaksi antara kultivar dengan media. Berdasarkan uji F, perbedaan nyata terjadi pada perlakuan media, sedangkan untuk perlakuan kultivar menunjukkan nilai yang tidak berbeda nyata (Tabel 1). Thorpe (1987) dan Davies (1995) melaporkan bahwa sinergisme antara media dan eksplan yang dkulturkan akan mempengaruhi pertumbuhan eksplan. Komposisi media dasar yang berbeda akan mempengaruhi respon jaringan yang dikulturkan, meskipun tidak selalau harus terjadi interaksi pada periode pertumbihan eksplan. Secara khusus Tiwari et al. (2004) melaporkan hasil penelitiannnya pada tanaman kedelai bahwa latar belakang genetik dan lingkungan kultur mempengaruhi pembentukan kalus dan regenerasi.

Media MS menunjukkan nilai rata-rata tertingi untuk karakter jumlah daun yaitu 28 buah, tinggi tunas $2,25 \mathrm{~cm}$ dan bobot basah planlet $0,69 \mathrm{~g}$, sedangkan media pupuk anorganik Hyponex memberikan nilai rata-rata tertinggi untuk karakter jumlah akar, yaitu 56 buah dan panjang akar 1,85 cm. Karakter jumlah tunas dan waktu awal pembentukan tunas media menunjukkan pengaruh yang sama.

\section{Kesimpulan dan Saran}

\section{Kesimpulan}

1. Tidak terdapat interaksi antara kultivar Nilam dengan media untuk karakter waktu awal pembentukan tunas, tinggi tunas, jumlah daun, jumlah akar, panjang akar, dan bobot basah planlet.

2. Media MS menunjukkan pengaruh terbaik untuk karakter, jumlah daun, tinggi tunas dan bobot basah planlet. Media pupuk anorganik Hyponex menunjukkan pengaruh terbaik untuk karakter jumlah akar dan panjang akar.

Saran. Penelitian ini sebaiknya dilanjutkan dengan Menggunakan jenis pupuk Anorganik yang berbeda yang dapat menaikkan jumlah daun, tinggi tunas dan bobot planlet

\section{Ucapan Terima Kasih}

Direktorat Riset dan Pengabdian Masyarakat Universitas Padjadjaran Bandung yang telah mendanai sebagian penelitian ini. Ucapan terima kasih juga disampaikan kepada semua pihak yang telah membatu penelitian ini.

\section{Daftar Pustaka}

Balai Penelitian Tanaman Obat dan Rempah. 2006. Rata-Rata Produksi Terna, Kadar Minyak, Produksi Minyak, dan Kadar Patchouli Alkohol Tiga Varietas Nilam dan Klon Lokal di Tiga Lokasi Selama Dua Musim panen.

Crowder, L.V. 1990. Genetika Tumbuhan. Terjemahan Lilik Kusdarwati dan Sutarso. Gadjah Mada University Press. Yogyakarta.

Davies, P.J. 1995. The plant hormone their nature, occurence and function. In Davies 
(ed.) Plant Hormone and Their Role in Plant Growth Development. Dordrecht Martinus Nijhoff Publisher.

Gaspersz, V. 1995. Teknik Analisis dalam Penelitian Percobaan. Tarsito. Bandung.

Gunawan L.W. 1992. Teknik Kultur Jaringan Tumbuhan. Depdikbud Dirjen Pendidikan Tinggi Pusat Antar Universitas Bioteknologi. Institut Pertanian Bogor. Bogor.

Hadi, S. 2006. Sekilas Kultur Jaringan anggrek Skala rumah tangga.

Krismawati A. 2005. Nilam dan Potensi Pengembangannya Kalteng Jadikan Komoditas Rintisan. Tabloid Sinar Tani. Kalimantan.

Mangun. 2008. Nilam. Penebar Swadaya. Jakarta.

Nuryani, Y. 2006. Budidaya Tanaman Nilam (Pogostemon cablin Benth.). Balai Penelitan
Tanaman Rempah Dan Aromatik -Pusat Penelitian Dan Pengembangan Perkebunan Badan Penelitian Dan Pengembangan Pertanian

Soedjono, S dan Kamidjono. 1992. Penggunaan medium pupuk daun dan konsentrasi air kelapa bagi perumbuhan protocorm anggrek Dendrobium ekapol Panda In Vitro. Jurnal Hortikultura Vol. 2(1)

Thorpe, T.A. 1987. Micropropagation of softwood and hard woods. Proceeding of the Seminar on Tissue Culture of Forest Species. Kualalumpur, 15-18 Juni.

Tiwari, S., P.Shanker and M. Tripathi. 2004. Effects of genotype and culture medium on in Vitro androgenesis in soybean (Glycine max Merr.). Indian Journal of Biotechnology Vol 3, July 2004, pp 441-444 